\title{
SISTEM PENDUKUNG KEPUTUSAN PEMILIHAN LOKASI PREWEDDING MENGGUNAKAN METODE WEIGHT PRODUCT
}

\author{
Muhammad Riza Syahputra $^{1}$, Riki Winanjaya ${ }^{2}$, Harly Okprana ${ }^{3}$ \\ ${ }^{1}$ STKIP AL MAKSUM LANGKAT \\ ${ }^{2,3}$ AMIK TUNAS BANGSA
}

Email: ${ }^{1}$ Muhammadrizafx@mybox.id, ${ }^{2}$ Riki@ amiktunasbangsa.ac.id, ${ }^{2}$ Harlyi@ amiktunasbangsa.ac.id

\begin{abstract}
Abstrak
Pernikahan merupakan momen yang paling ditunggu setiap orang. Foto prawdding merupakan suatu hal yang penting yang dilakukan sebelum pernikahan. Karena foto prewedding menjadi kan tren terkini untuk foto yang akan di tampilkan saat pernikahaan. Namun dalam foto prewedding banyak sekali calon pengantin yang tidak puas dengan hasil foto prewedding tersebut. Sistem ini dapat memudahkan calon pengantin dalam melakukan pemilihan lokasi foto prawedding tanpa perlu bertemu langsung untuk berkonsultasi. Sistem pengambilan keputusan ini dibuat mengunakan metode Weight Product serta dibuat dengan bahasa pemrograman php dan database MySQL. Metode WP digunakan untuk mencari alternatif optimal dari sejumlah alternatif yang ada.pemilihan lokasi foto prewedding menggunakan pembobotan untuk setiap kriterianya. Calon pengantin dapat memilih lokasi yang diinginkan berdasarkan kriteria yaitu jumlah spot, tema, jarak lokasi, jumlah shoot dengan bobot yang ditentukan oleh user berdasarkan tingkat kepentingan. Hasil dari sistem ini yaitu menampilkan lokasi praweding berdasarkan rating lokasi foto prawedding yang dapat dipesan oleh calon pengantin. Pemilihan lokasi foto prewedding dapat dilakukan dengan optimal sehingg a hasil keputusan sesuai dengan yang diharapkan.
\end{abstract}

Kata Kunci: Sistem Pendukung Keputusan, Lokasi Prewedding, Weight Product

\begin{abstract}
Marriage is the most awaited moment for everyone. Prawdding is an important thing to do before a wedding. Because prewedding photos become the latest trend for photos that will be displayed during the wedding. But in a lot of prewedding photos brides who are not satisfied with the results of these prewedding photos. This system can facilitate the bride and groom in choosing the location of prawedding photos without the need to meet in person to consult. This decision making system is made using the Weight Product method and is made with the php programming language and MYSQL database. The WP method is used to find optimal alternatives from a number of alternatives. The selection of the location of the prewedding photo uses weighting for each criterion. The bride and groom can choose the desired location based on criteria such as the number of spots, themes, location distance, number of shoots with weights determined by the user based on the level of importance. The results of this system are displaying praweding locations based on the location of prawedding photos that can be ordered by the bride and groom. The selection of prewedding photo locations can be done optimally so that the results of the decision are as expected.
\end{abstract}

Keywords: Decision Support System, Prewedding Location, Product Weight

\section{PENDAHULUAN}

Perkembangan teknologi fotografi saat ini berkembang sangat pesat, sehingga para konsumen sering merasa ragu saat harus memutuskan langsung memilih lokasi foto prewedding untuk acara mereka. Lokasi foto prewedding merupakan bagian dari sebuah kebagaiaan yang sering diabadikan untuk sebuah pernikahan. Konsumen harus lebih teliti dalam memilih lokasi foto prewedding yang akan digunakan untuk foto shoot. Pemilihan lokasi perlu beberapa pertimbangan yang harus dimengerti. Pertimbangan - pertimbangan tersebut adalah lokasi foto, transportasi, biaya dan lain - lain

Selama ini masyarakat atau calon pengguna jasa foto prewedding untuk memilih lokasi foto berdasarkan saran dari teman saja yang akan menjadi pilihannya dan tidak memiliki kriteria - kriteria khusus dalam menentukan pilihannya. Seperti angle view, jarak lokasi foto, jumlah spot area, perfect spot dan lain - lain. Hal ini lah yang menjadi salah satu hal yang menimbulkan berbagai masalah yang di menggunakan jasa foto prewedding .

Sistem pendukung keputusan penentuan lokasi foto prawedding merupakan suatu cara atau metode yang bertujuan mengklasifikasikan secara rinci guna mencegah kesalahan pemilihan lokasi foto yang tidak sesuai dengan temanya karena faktanya yang ada dilapangan ketika akan lokasi tidak sesuai dengan harapan dan tema. Hasil dari proses sistem pendukung keputusan penentuan lokasi foto ini berupa klasifikasi lokaso sebagai rekomendasi bagi pengambilan keputusan untuk memilih lokasi yang cocok untuk dijadikan background prewedding yang sesuai dengan kriteria yang ada. Setiap lokasi mempunyai nilai yang berbeda-beda terhadap aspek yang diinginkan, penentuan lokasi mana yang diinginkan perlu sebuah alat bantu yang tepat, yaitu dengan menggunakan komputer sebagai suatu sarana yang dapat membantu. Penerapan metode banyak digunakan untuk menyelesaikan masalah seleksi lokasi foto prawedding, salah satu metode yang diterapkan adalah Weight Product. Sehingga diharapkan proses seleksi lokasi foto prawedding akan lebih tepat dan hasilnya bias digunakan sebagai acuan dalam pengambilan keputusan secara tepat.

Berdasarkan penelitian Aziz Ahmadi dan Dian Triyianti. “Implementasi Weighted Product (WP) dalam Penentuan Penerima Bantuan Langsung Masyarakat PNPM Mandiri Perdesaan”. Hasil penentuan perangkingan usulan kegiatan pada PNPM dipilih 5 besar preferensi tertinggi dengan menggunakan beberapa alternative. Metode weigted product yang sederhana dan mudah untuk diterapkan dalam kasus kasus yang masih tinggi unsur 
subjektivitasnya.Isi pendahuluan mengandung latar belakang, tujuan, identifikasi masalah dan metode penelitian, yang dipaparkan secara tersirat (implisit). Kecuali bab Pendahuluan dan bab Kesimpulan, penulisan judul-judul bab sebaiknya eksplisit menyesuaikan isinya. Tidak harus implisit dinyatakan sebagai Dasar Teori, Perancangan, dan sebagainya.

\section{METODE PENELITIAN}

\subsection{Sistem}

Sistem adalah suatu jaringan kerja dari prosedur-prosedur yang saling berhubungan, berkumpul bersamasama untuk melakukan kegiatan atau untuk melakukan sasaran yang tertentu. Pendekatan sistem yang merupakan jaringan kerja dari prosedur lebih menekankan urutan-urutan di dalam sistem[4].

\subsection{Sistem Pendukung Keputusan}

Sistem Penunjang Keputusan adalah sistem yang membantu pengambil keputusan dengan melengkapi mereka dengan informasi dari data yang telah diolah dengan relevan dan diperlukan untuk membuat keputusan tentang suatu masalah dengan lebih cepat dan akurat. Sehingga sistem ini tidak dimaksudkan untuk menggantikan pengambilan keputusan dalam proses pembuatan keputusan[2].

Sebuah sistem terdiri dari berbagai unsur yang saling melengkapi dalam mencapai tujuan dan sasaran. Unsurunsur yang terdapat dalam sistem itulah yang disebut dengan subsistem. Subsistemsubsistem tersebut harus saling berhubungan dan berinteraksi melalui komunikasi yang relevan sehingga sistem dapat bekerja secara efektif dan efisien[3].

\subsection{Weight Product}

Metode WP merupakan salah satu dari beberapa metode MADM (Multi Atribute Decision Making). Metode MADM merupakan metode pengambilan keputusan yang didasarkan pada beberapa atribut. Konsep permasalahannya adalah mengevaluasi $\mathrm{m}$ alternatif $\mathrm{Ai}(\mathrm{i}=1,2, \ldots, \mathrm{m})$ terhadap sekumpulan atribut atau kriteria $\mathrm{Cj}$ $(\mathrm{j}=1,2, \ldots, \mathrm{n})$, dimana setiap atribut tidak saling bergantung satu dengan yang lainnya. Metode ini mengharuskan pembuat keputusan menentukan bobot bagi setiap atribut[1].

Metode WP menggunakan proses normalisasi, dimana rating setiap atribut harus dipangkatkan dahulu dengan bobot atribut yang bersangkutan. Proses ini diberikan dengan rumus sebagai berikut:

$$
S_{i}=\prod_{j=1}^{n}=X_{i j^{w j}} \quad(1)
$$

dengan $\mathrm{i}=1,2, \ldots, \mathrm{m}$, dimana :

$\mathrm{S}$ menyatakan preferensi alternatif,

$\mathrm{x}$ menyatakan nilai kriteria,

w menyatakan bobot kriteria,

n menyatakan banyaknya kriteria.

$\mathrm{Wj}$ adalah pangkat bernilai positif untuk atribut keuntungan, dan bernilai negatif untuk atribut biaya.

Preferensi relatif dari setiap alternatif diberikan sebagai :

$V_{i}=\frac{\prod_{j=1}^{n} x_{i j}^{w j}}{\prod_{j=1}^{n}\left(X_{j}\right)^{w j}}$

dimana :

$\mathrm{V}:$ Preferensi alternatif,

$\mathrm{X}$ : Nilai kriteria,

w : Bobot kriteria.

Alternatif yang akan dipilih adalah 5 besar yang memiliki nilai preferensi tertinggi.

Adapun bobot adalah nilai atau tingkat kepentingan relatif dari setiap kriteria (Cj) yang diberikan oleh decision maker, dalam hal ini adalah TV. Nilai bobot diberikan sebagai

$\mathrm{W}=\{\mathrm{w} 1, \mathrm{w} 2, \mathrm{w} 3, \ldots, \mathrm{wn}\}$

di mana nilai $=1$

\subsection{Prewedding}

Prewedding adalah salah satu tren tersendiri bagi pasangan yang ingin menikah, banyak sekali foto pre wedding outdoor yang menjadi inspirasi banyak pasangan muda yang ingin menyambut Pernikahan dengan membuat foto semacam ini. Foto adalah salah satu bukti cinta kasih anda, dengan sebuah foto, apalagi pre wedding tentu akan membuat pernikahan anda semakin meriah.

\section{ANALISA DAN PEMBAHASAN}


Analisia pada sistem yang berjalan bertujuan untuk mengetahui jelas bagaimana cara kerja sitem pendukung keputusan tersebut berjalan, sehngga kelebihan dan kekurangan sistem pendukung kerputusan dapat di ketahui dengan cara menerakan metode Weigtheed Product (WP)

\subsection{Analisis Metode Weighted Product (WP)}

Dalam sistem pendukung keputusan lokasi foto prawedding yang baik dengan menggunakan mettode Weighted Product (WP) di perlukan kriteria kriteria dan bobot untuk melakukan perhitungannya sehingga akan di dapat alternative terbaik

\subsubsection{Kriteria}

Penentuan lokasi foto prawedding dengan menggunakan weighted product terdapat kriteria yang dibutuhkan untuk menentukan siapa yang akan terpiliih sebagai lokasi foto prawedding dengan kriteria yang telah di tentukan. Adapun kriterianya adalah sebagai berikut :

Tabel 1. Tabel Kriteria

\begin{tabular}{cc}
\hline Inisialisai Kriteria & Kriteria \\
\hline C1 & Jarak lokasi \\
C2 & Jumlah spot \\
C3 & Transportasi \\
C4 & Waktu \\
C5 & Biaya lokasi \\
C6 & Tema \\
\hline
\end{tabular}

Tabel 2. Nilai Jarak Lokasi

\begin{tabular}{cc}
\hline Jarak Lokasi & Nilai \\
\hline$<20 \mathrm{~km}$ & 5 \\
$<50 \mathrm{~km}$ & 4 \\
$<100 \mathrm{~km}$ & 3 \\
$<150 \mathrm{~km}$ & 2 \\
$150 \mathrm{~km}>$ keatas & 1 \\
\hline
\end{tabular}

Tabel 3. Nilai Transportasi

\begin{tabular}{cc}
\hline Tranportasi & Nilai \\
\hline Mobil Pribadi & 3 \\
Bus & 2 \\
Pesawat & 1 \\
\hline
\end{tabular}

Tabel 4. Nilai Waktu

\begin{tabular}{cc}
\hline Waktu & Nilai \\
\hline 1 hari & 5 \\
2 hari & 4 \\
3 hari & 3 \\
4 hari & 2 \\
5 hari keatas & 1 \\
\hline
\end{tabular}

Tabel 5. Nilai Biaya Lokasi

\begin{tabular}{cc}
\hline Biaya Lokasi & Nilai \\
\hline$<$ Rp. 100.000 & 5 \\
Rp. $250.000>$ Rp. 500.000 & 4 \\
Rp. $500.000>$ Rp. 750.000 & 3 \\
Rp. $750.000>$ Rp. 1.000 .000 & 2 \\
Rp. $1.000 .000>$ & 1 \\
\hline
\end{tabular}

\begin{tabular}{|c|c|}
\hline \multicolumn{2}{|c|}{ Tabel 6. Nilai Tem } \\
\hline Tema & Nilai \\
\hline Indoor & 2 \\
\hline Outdor & 1 \\
\hline
\end{tabular}

\subsubsection{Alternatif}


Alternatif Ai dengan $\mathrm{i}=1,2, \ldots, \mathrm{m}$ adalah obyek-obyek yang berbeda dan memiliki kesempatan yang sama untuk dipilih oleh pengambil keputusan. Data yang digunakan adalah data lokasi yang diajukan dalam penentuan lokasi foto prawedding sebagai berikut :

Tabel 7. Alternatif

\begin{tabular}{cc}
\hline Inisialisai Alternatif & Alternatif \\
\hline A1 & Kito art cafe \\
A2 & Rumah pohon \\
A3 & Rumah terbalik \\
A4 & Desa-desa resto \\
A5 & Cafe sosmed \\
A6 & Masjid raya \\
\hline
\end{tabular}

\subsubsection{Bobot}

Adapun bobot adalah nilai atau tingkat kelayakan relatif dari setiap kriteria (Cj) yang diberikan oleh decision maker. Nilai bobot diberikan sebagai berikut :

Tabel 8. Nilai Bobot

\begin{tabular}{lc}
\hline \multicolumn{1}{c}{ Tingkat Kelayakan } & Bobot \\
\hline Sangat Penting & 5 \\
Penting & 4 \\
Cukup Penting & 3 \\
Tidak Penting & 2 \\
Sangat Tidak Penting & 1 \\
\hline
\end{tabular}

\subsubsection{Nilai Bobot Setiap Kriteria}

Adapun data hubungan antara alternatif dan kriteria terlihat pada TABEL 9 . Nilai-nilai tersebut merupakan nilai yang diberikan oleh pakar untuk usulan kegiatan yang diajukan oleh data alternatif.

Tabel 9. Nilai Bobot untuk setiap kriteria

\begin{tabular}{lcc}
\hline Kriteria & Tingkat Kepentingan & Bobot \\
\hline Jarak lokasi & Penting & 4 \\
Jumlah spot & Sangat penting & 5 \\
Transportasi & Penting & 4 \\
Waktu & Penting & 4 \\
Biaya lokasi & Penting & 4 \\
Tema & Cukup Penting & 3 \\
\hline
\end{tabular}

Tabel 10. Nilai alternatif dan Kriteria

\begin{tabular}{ccccccc}
\hline \multirow{2}{*}{ Alternatif (Ai) } & \multicolumn{7}{c}{ Kriteria (Ci) } \\
\cline { 2 - 7 } & C1 & C2 & C3 & C4 & C5 & C6 \\
\hline Kito art cafe & 5 & 8 & 3 & 5 & 2 & 1 \\
Rumah pohon & 4 & 7 & 3 & 5 & 3 & 1 \\
Rumah terbalik & 4 & 10 & 3 & 5 & 3 & 1 \\
Desa-desa resto & 3 & 5 & 3 & 5 & 2 & 1 \\
Cafe sosmed & 5 & 8 & 3 & 5 & 3 & 1 \\
Masjid raya & 5 & 4 & 2 & 4 & 4 & 1 \\
\hline
\end{tabular}

\subsubsection{Penyelesaian perhitungan}

Setelah menentukan kriteria dan menentukan rating kecocokan setiap alternatif lalu menyelesaikan perhitungan dengan menggunakan rumus Weighted Product:

Sebelum dilakukan perbaikan bobot terlebih dahulu, sehingga total bobot $\sum w j=1$ dengan cara

$W_{J}=\frac{W_{j}}{\sum W_{j}}$

dimana :

$\mathrm{Wj} \quad=\mathrm{W}$ index ke $\mathrm{j}$

$\sum \mathrm{wj}=$ jumlah dari $\mathrm{W}$

Dari bobot preferensi sebelumnya yaitu $\mathrm{W}=(4,5,4,4,4,3)$. Wj merupakan $\mathrm{W}$ index ke j. jadi untuk W1 yaitu 3 , W2 yaitu 4 dan seterusnya. Dan $\sum w j$ merupakan jumlah dari W yaitu $4+5+4+4+4+3$. Jadi untuk perbaikan bobot W1 menjadi 
$W 1=\frac{4}{4+5+4+4+4+3}=0,167$

$W 2=\frac{5}{4+5+4+4+4+3}=0,208$

$W 3=\frac{4}{4+5+4+4+4+3}=0,167$

$W 4=\frac{4}{4+5+4+4+4+3}=0,167$

$W 5=\frac{3}{4+5+4+4+4+3}=0,125$

Menetukan nilai vector Si yang dapat dihitung menggunakan formula berikut

$S_{i}=\prod_{j=1}^{n} X_{i j}{ }^{w j}$

dimana :

$\mathrm{V}:$ Preferensi alternatif,

$\mathrm{X}$ : Nilai kriteria,

w : Bobot kriteria.

Untuk perhitungan sederhananya kembali lihat table nilai alternatif dan kriteria pada bari R1, masing masing kritteria memiliki nilai sebagai berikut:

$\mathrm{C} 1=5$

$\mathrm{C} 2=8$

$\mathrm{C} 3=3$

$\mathrm{C} 4=5$

$\mathrm{C} 5=2$

$\mathrm{C} 6=1$

Pangkatkan dan kalikan nilai masingg-masing kriteria tersebut dengan bobot yang sudah diperbaiki sebelumnya menjadi seperti berikut $S 1=\left(5^{0,167}\right)\left(8^{0.208}\right)\left(3^{0.167}\right)\left(5^{0.167}\right)\left(2^{0.167}\right)\left(1^{-0.125}\right)=3,5549$

Dan seterusnya hingga S6 telah dilakukan proses normalisasi sehingga di dapat hasil normalisasi sebagai berikut.

Tabel 11. Hasil Perhitungan Nilai Si

\begin{tabular}{ll}
\hline $\mathrm{Si}$ & Nilai Si \\
\hline $\mathrm{S} 1$ & 3,5549 \\
$\mathrm{~S} 2$ & 3,5640 \\
$\mathrm{~S} 3$ & 3,8389 \\
$\mathrm{~S} 4$ & 2,9602 \\
S5 & 3,8034 \\
S6 & 3,1102 \\
\hline
\end{tabular}

Menentukan nilai vector yang akan digunakan mengehitung preferensi (Vi) untuk perangkingan adalah sebagai berikut

$$
V 1=\frac{S 1}{S 1+S 2+S 3+S 4+S 5+S 6}
$$

Jadi hasil dari menghitung preferensi (Vi) adalah sebagai berikut :

$$
\begin{aligned}
& \mathrm{V} 1=\frac{3.5549}{3.5549+3.5640+3.8389+2.9602+3.8034+3.1102}=0.1706 \\
& \mathrm{~V} 2=\frac{3.5640}{3.5549+3.5640+3.8389+2.9602+3.8034+3.1102}=0.1711 \\
& \mathrm{~V} 3=\frac{3.8389}{3.5549+3.5640+3.8389+2.9602+3.8034+3.1102}=0.1843 \\
& \mathrm{~V} 4=\frac{2.9602}{3.5549+3.5640+3.8389+2.9602+3.8034+3.1102}=0.1421 \\
& \mathrm{~V} 5=\frac{3.8034}{3.5549+3.5640+3.8389+2.9602+3.8034+3.1102}=0.1826 \\
& \mathrm{~V} 6=\frac{3.1102}{3.5549+3.5640+3.8389+2.9602+3.8034+3.1102}=0.1493
\end{aligned}
$$

Dari hasil perhiungan diatas, Nilai V3 menunjukan nilai terbesar sehingga dengan kata lain V3 merupakan pilihan alternative yang terbaik yang layak ditentukan sebagai lokasi foto prawedding sesuai dengan pembobotan yang diberikan oleh pengambilan keputusan 


\section{IMPLEMENTASI}

Implementasi antarmuka dilakukan pada setiap halaman aplikasi yang sudah dibuat dan dalam bentuk file program. Implementasi rancangan antar muka dengan menggunakan Bahasa pemograman PHP, design form menggunakan software Adobe Dreamweaver CS6. Berikut akan dijelaskan langkah-langkah aplikasi sistem pendukung keputusan penentuan lokasi prawedding terbaik dengan menggunakan metode weight product (WP)

Untuk menjalankan sistem ini dengan program menjalankan program ini dengan mengakses pada halaman web. Saat ini sistem belum terdapat digunakan pada kantor mata kamera, sehingga diharapkan dapat lebih memudahkan dalam penentuan lokasi prawedding terbaik dengan tepat dan pasti

1. Halaman Login Area

Pada halaman login user dapat mengakses atau masuk kedalam sistem pendukung keputusan dalam penentuan lokasi prawedding terbaik dengan menggunakan metode weight product (WP), terlebih dahulu harus memasukkan username dan password setelah itu klik login.

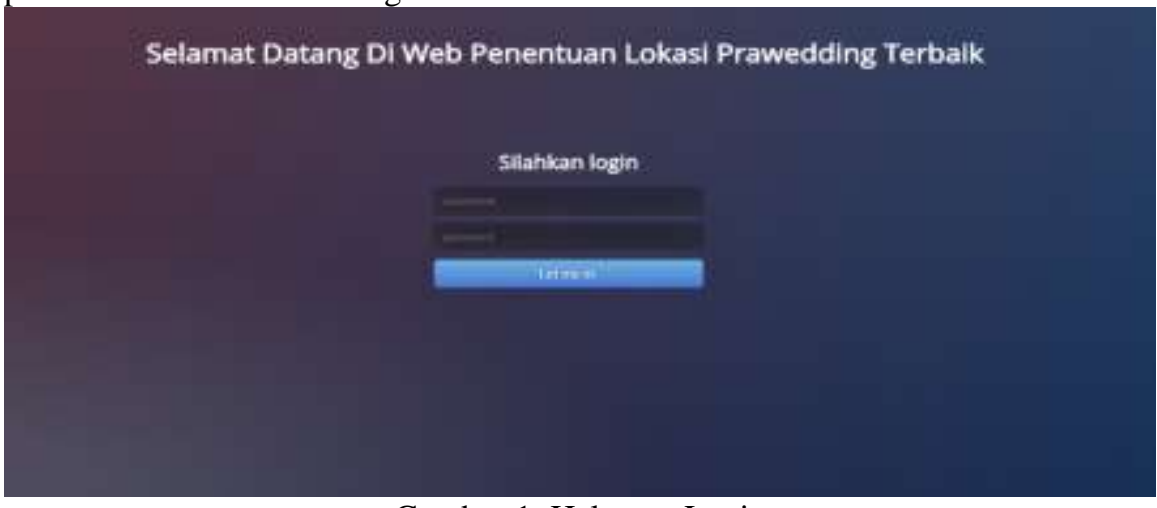

2. Halaman Menu Utama

Gambar 1. Halaman Login

Pada halaman awal sistem pendukung keputusan dalam penentuan lokasi prawedding terbaik dengan menggunakan metode weight product (WP) user dapat melihat pada bagian atas tampilan, terdapat menu home, ranking, About us, Contact us dan logout. User dapat memilih salah satu menu diatas

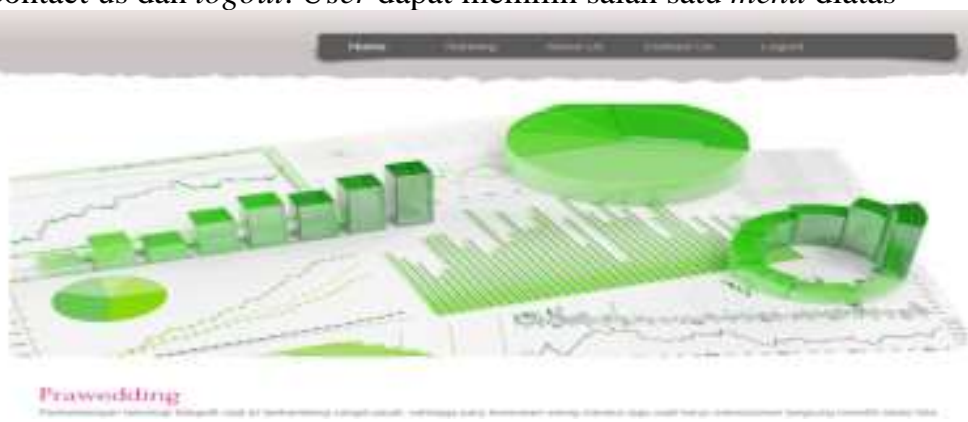

Gambar 2. Halaman Menu Utama

3. Halaman Rangking

Pada halaman produk sistem pendukung keputusan dalam penentuan lokasi prawedding terbaik dengan menggunakan metode weight product ( $w p$ ) user dapat menambahkan data lokasi yang belum terdapat di dalam sistem. User juga dapat menghapus dan mengedit jika terdapat kesalahan terhadap data customer yang telah di inputkan. Lalu jika sudah selesai user dapat mengklik tombol menu diatas untuk kembali ke halaman utama

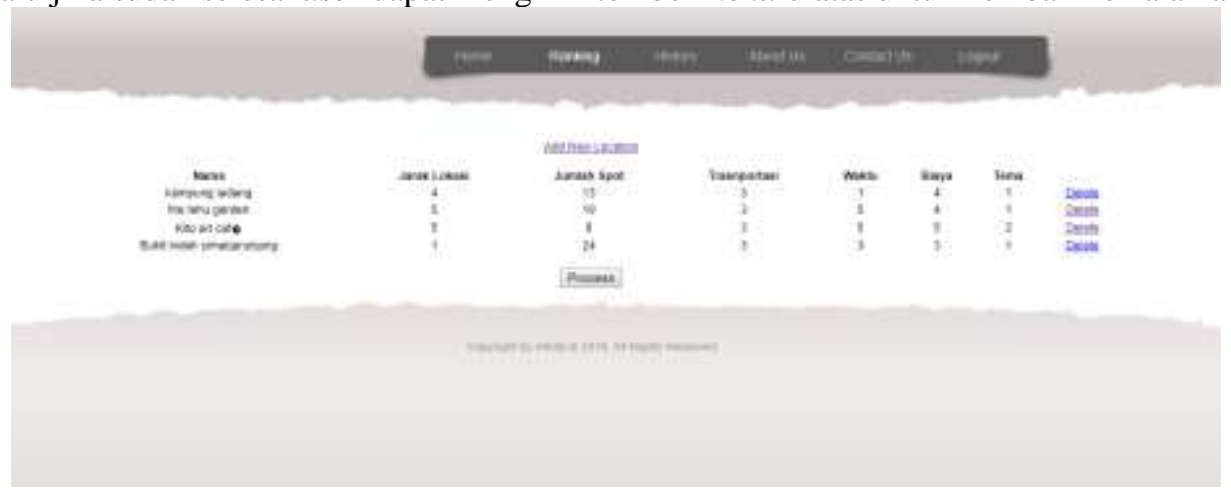

Gambar 3. Halaman Ranking 
4. Halaman Laporan

Pada halaman laporan sistem pendukung keputusan dalam lokasi prawedding terbaik dengan menggunakan metode weight product (WP), user dapat melihat hasil laporan yang telah di hitung dan dapat mencetak file tersebut. Pada halaman ini semua data yang ditampilkan. User dapat mencetaknya semudah mencetak kertas pada printer biasa.

\section{DATA RANGKING PEMILIHAN FOTO PRAWEDDING}

A. Uma Bavi, Keiurahan Paya Robo, Kecamatan Binjä Bard, Kota Binjai, Sumatera Utara 20718

\begin{tabular}{|c|c|c|c|}
\hline NO NO ID & Nama Lokasi & Nilai Ranking \\
\hline 1 & $\mathrm{~K} 0002$ & the lehu garden & 0.28663107685729 \\
\hline 2 & $\mathrm{~K} 0003$ & Kito art calé & 0.26044811304899 \\
\hline 3 & $\mathrm{~K} 0004$ & Bukit indah simarjaruniung & 0.2300200601352 \\
\hline 4 & $\mathrm{~K} 0001$ & kampung ladang & 0.22290074995851 \\
\hline
\end{tabular}

Gambar 4. Halaman Laporan

\section{KESIMPULAN}

Sistem pendukung keputusan penetuan lokasi prawedding terbaikdengan menggunakan metode Weight Product (WP) dapat dijadikan sebagai salah satu solusi dalam menyelesaikan permasalahan penentuan lokasi prawedding terbaikdengan baik untuk dapat memberikan bantuan secara tepat, dengan menerapkan 6 kriteria yang ada seperti jarak lokasi, jumlah spot, trasportasi, waktu, biaya lokasi dan tema. Proses penentuan lokasi prawedding terbaik bisa dilakukan lebih akurat dan tepat dibanding dengan hanya pengecekan dan perkiraan. Kesimpulan yang didapat pada penelitian ini adalah sebagai berikut :

1. Pengambilan keputusan untuk penentuan lokasi prawedding terbaik lebih terperinci agar customer bisa mendapatkan lokasi foto yang benar-bernar sesuai dengan kebutuhan keluarga tersebut dengan layak dan bagus.

2. Metode Weight Product (WP) mampu menyelesaikan persoalan pemilihan lokasi prawedding terbaik dengan baik

\section{REFERENCES}

[1] Ahmadi, A., \& Wiyanti, D. T. (2014). Implementasi Weighted Product (WP) dalam Penentuan Penerima Bantuan Langsung Masyarakat PNPM Mandiri Perdesaan. Seminar Nasional Aplikasi Teknologi Informasi, 19-22.

[2] Eko Darmanto, Noor Latifah, N. S. (2014). Penerapan Metode Ahp ( Analythic Hierarchy Process ) Untuk Menentukan Kualitas Gula Tumbu. Jurnal SIMETRIS, 5(1), 75-82.

[3] Iswandy, E., Sekolah, D., Manajemen, T., Komputer, I., \& Balantai, B. (2015). Jurnal TEKNOIF ISSN : 2338-2724 SISTEM PENUNJANG KEPUTUSAN UNTUK MENENTUKAN PENERIMAAN MAHASISWA DAN PELAJAR KURANG MAMPU Vol . 3 No . 2 Oktober 2015 Jurnal TEKNOIF ISSN : 2338-2724, 3(2).

[4] T. Henny Febriana Harumy ,Julham Sitorus, M. L. (2018). SISTEM INFORMASI ABSENSI PADA PT. COSPAR SENTOSA JAYA MENGGUNAKAN BAHASA PEMPROGRAMAN JAVA. JURNAL TEKNIK DAN INFORMATIKA, 9(2), 208-208. https://doi.org/10.1111/j.1445-5994.1979.tb04333.x 